\title{
A panorama of portraits: Elements of empathy in the Yiddish poems of David Fram
}

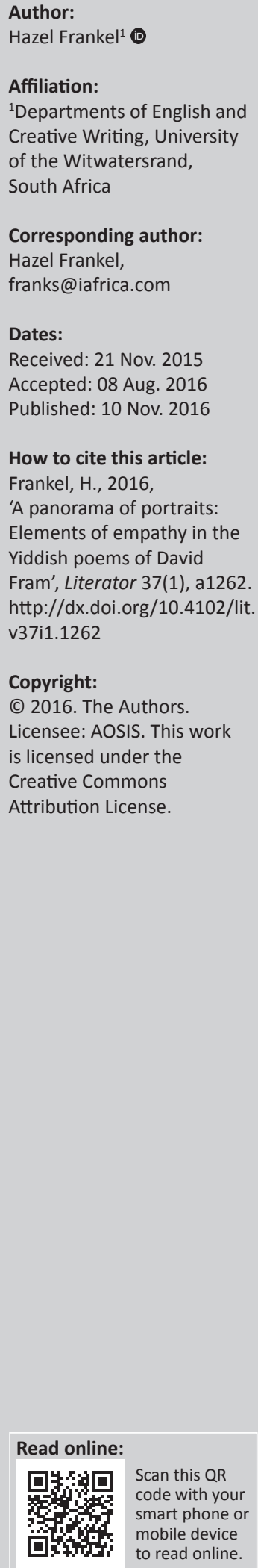

David Fram created a rich body of poetry in his mother tongue, Yiddish. This article offers detailed readings that reflect elements of empathy in his poetic responses to people he knew in Lithuania, in those referring to the strangers he encountered in South Africa, as well as to victims of the Holocaust. In making the poems available to a wider audience through my translations and transliterations, I argue for their continued relevance as vehicles for a deeper understanding of these issues.

'n Portretpanorama: Empatiese inlewing in David Fram se Jiddisje gedigte. David Fram het 'n ryk versameling poësie in sy moedertaal, Jiddisj, geskryf. Hierdie artikel bied gedetailleerde lesings aan van gedigte wat die digter se empatiese digterlike reaksie weerspieël op mense wat hy in Litaue geken het, vreemdelinge wat hy in Suid-Afrika ontmoet het, asook op slagoffers van die Shoa. Deur die gedigte beskikbaar te stel vir 'n wyer gehoor deur my vertalings en transliterasies, probeer ek hulle voortgesette relevansie as draers van 'n dieper begrip van hierdie kwessies aantoon.

\section{Introduction}

David Fram's Yiddish poems frequently evoke his observation of people and his reactions to their circumstances and their suffering. With reference to my own English translations and transliterations, ${ }^{1}$ this article highlights selected poems that particularly reflect the poet's empathy in his responses to his familiars in Lithuania, the strangers he encountered in South Africa and towards victims of the Holocaust. Further, it also suggests that Fram's response to the fate of these victims provides an example of Dominick LaCapra's notion of 'empathic unsettlement' (2001:102). Thus, while also asserting their inherent literary value, this article argues for the poems' continuing relevance in our tumultuous, multicultural world.

Where conflict continues to flare around issues of race and colour, literature may allow us to enter into and imagine the lives of others. Fram's Yiddish poems provide one useful prism through which to do so. In that they contain his personal responses to historical events, they provide examples of 'literary writing giv[ing] form and meaning to something poignant' (Stonebridge \& Potter 2014:2), an expression of 'a sensibility attuned to the pain of others' (Hunt 2008:39). This article also argues for their continued relevance, as well as for Yiddish literature, and, more specifically, for its poetry. While making no claim to poetry's ability to change the world or the status quo, it suggests that the poems reflect the circumstances of a particular individual at a specific time and place in history, as well as encompassing compassion and empathy for the observed other.

\section{Locating David Fram}

Born in 1903 in Ponevezh, Lithuania, Fram received a traditional Jewish education and also studied with private tutors. At the start of World War I, he and his family were relocated, as were many other Jewish families who lived in the Pale of Settlement. ${ }^{2}$ This was the first of many times that Fram experienced the vicissitudes of migration and displacement. Fram matriculated at a Russian Soviet workers' school before returning to Ponevezh in 1921. He then attended the Yiddish academy in Ukmerge, ${ }^{3}$ where Yudl Mark, the linguist and lexicographer became his tutor and mentor. Although Fram's first-published poem, 'Zima' ['Winter'], was written in Russian 1.This refers to Yiddish written in Latin characters from left to right.

2.The Russian Jews in czarist times were forced to reside in the Pale of Settlement, the frontier area between the Austro-Hungarian and Russian Empires.

3.Ukmerge is Lithuanian. The town is known as Wilkomir in Yiddish, Vilkmerge in Russian 
and appeared in a Russian journal, thereafter he always wrote in Yiddish (Sherman 2006:7). As one of thousands in a 'chain of immigration' (Simon 2009:114), Fram left Lithuania in 1927 to join an uncle in South Africa, the golden country, di

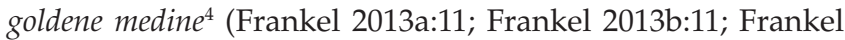
2015:23).

'Poems, novels and plays, it is claimed, are the very stuff of the human, [and] writing is about how we perceive, narrate, feel and experience the world' (Stonebridge \& Potter 2014:2). The journals and newspapers in which Fram's poems appeared represent the full gamut of literary and political outlooks of the times: Kveytn [Blossoms] (Ponevezh), Yidishe shtime [Yiddish Voice] and Folksblat [People's Paper] (Kovno). Later poems written between 1924 and 1931 were published in Der Velt [The World] (Lite), Literarishe bleter [Literary Pages] ${ }^{5}$ and Haynt [Today] (Warsaw), Nayes [News], Mir Aleyn [Ourselves Alone] and Kovner Tog [Kovno Day] (Kovno), Der Shtral [The Ray] (Libau, Latvia), Di Vokh [The Week] (Riga, Latvia), as well as Zuntog [Sunday] and Oyfkum [Arrival] (New York). In South Africa, Fram's poems appeared in Dorem Afrike [South Africa], Yidishe Tribune [Yiddish Tribune], Foroys [Forward] and Ekspres [Express] (Johannesburg), and Fri-Stayter Baginen [Free State Dawn] (Bloemfontein). Fram's (1931c) first collection Lider un poemes [Songs and poems] was published in Vilna. A shvalb oyfn dakh [A swallow on the roof] appeared in Johannesburg in 1983 (Frankel 2013a:11; Frankel 2013b:11; Frankel 2015:23).

The discussion spans Fram's life as a whole, from his childhood growing up in Russia and family relationships, to his experience of migration and interactions in his new environment, and also his response to the Holocaust. It includes lyric poems about the landscape in Lithuania such as 'Shney' ['Snow'], 'Shkiye' ['Sunset'], 'Harbstik' ['Autumnal'], 'Shotns' ['Shadows'] and 'Shtilkayt' ['Silence']. He also wrote numerous poems concerning his experiences of diaspora and exile, including 'Mayn opfor' ['My departure'], 'Mayn mame hot mir tsugeshikt a kishn' ['My mother sent me a cushion'], 'Iz vos?' ['So what?'], 'Efsher' ['Perhaps'] and 'In tsveyen' ['Two fold']. 'Ikh benk' ['I long'] and 'Oyf mayn dakh hot amol gesvitshert a shvalb' ['Once a swallow twittered on my roof'] focus on his homeland as he remembered it, while his Holocaust poems include 'Dos letste kapitl' ['The last chapter'], 'Lesterung' ['Blasphemy'], 'Unzere kedoyshim' ['Our martyrs'] and 'An entfer der velt' ['An answer to the world']. Later poems concern the landscape and peoples of South Africa, including 'In an afrikaner baginen' ['In an African dawn'] and 'Oyftransvaler erd' ['On Transvaal earth'].

Discussing 'the high premium placed on empathy in contemporary human culture' (1. 6), Stonebridge and Potter suggest that 'the novel offers a special kind of conduit for sympathetic feelings' (1. 6). In spite of 'the paradoxes and difficulties of writing about the suffering of others'

\footnotetext{
4.After the assassination of Czar Alexander II in 1882; the Kishinev Pogrom; the RussoJapanese War, 1904-1905; the Failed Revolution of 1905; the Russian Revolution; and the First World War, thousands of Jews left to escape persecution, following family and friends in the hope of finding better economic opportunities elsewhere.

5.'Literarishe Bleter was the leading Yiddish literary journal in interwar Poland' (Cohen 2010)
}

(Stonebridge \& Potter 2014:6), this article suggests that the same may be said of poetry. Fram's lyrics 'Baym zeydn' ['At grandfather's'] (1931a) (1925-1926), ${ }^{6}$ Reb Yoshe in 'Reb Yoshe un zayn gortn' ['Reb Yoshe and his garden'] (1931d) (1927) and Reb Itshke of 'In a zunikn tog' ['On a sunny day'] (1931b) (1930), which were written in Lithuania; the South African poems, 'Fun shop tsu shop' ['From shop to shop'] (1984), 'Matumba' ['Matumba'] (1983b) and 'Burn' ['Farmers'] (1971b); and the Holocaust poem 'An entfer der velt' ['An answer to the world'] (1971a) offer a way of making empathy visible, as they reflect and/or produce feelings of empathy.

\section{Fram's Lithuanian portraits}

The lyric, 'Baym zeydn', a long verse-monologue, written after Fram had left Lithuania, conjures up memories of an idyllic boyhood. It also highlights the poet's empathy for the individual circumstances of another. Rather than distancing himself by 'objectification' (LaCapra 2001:105) of the other, Fram describes his close relationship with his grandfather whom he much admired, 'a gvar, a farbroynter fun zun un pukhiker velder'/'a strong man browned by the sun and downy woods' (1. 17), with 'pleytstes tsevaksene, breyte un hoykh' / 'well-developed shoulders, broad and tall' (1. 23). Rooted in the soil, 'Es hobn geshmekt zayne kleyder in reykhes fun tsaytike felder' / '[His] clothes reeked of the smell of ripe fields' (1. 19), the older man 'Farbroynte vi bronzene harbstn mit gilderne shtralen bazunte' /'Browned like bronzed autumns with gold sunny rays' (1. 24). This also suggests that his grandfather was so in tune with the seasons that his skin colour could be associated with that of autumn itself, so that, in touch with the land and its rhythms, he enjoys a symbiotic relationship with nature and the elements.

The poem's accretion of visual detail brings the poet's grandfather to life: 'Er hot in di velder di shvartse getogt un genekhtikt tsuzamen' /'He spent days and nights together in the woods' (1. 21), where he harvested 'bulbes'/'potatoes' (1. 20) and 'burikes royte, gezunte' /'healthy red beets' (1. 22). The tone is affectionate and respectful as the poet observes the older man going about his daily activities:

\footnotetext{
Tut oyset pamelekh der zeyde fun kop zayne tfiln

Un geyt unz tsu vekn: - di bulbes iz tsayt shoyn tsu grobn.

Nor mir viln keyner dem shlof aza zisn tseraysn.

[Slowly he took off his tefilin ${ }^{8}$ from his head

And went to wake us - the potatoes were ready for picking

But none of us want to tear ourselves away from our sleep.] (11. 35-37 [author's own translation])
}

Through personal interaction, the poet learns religious rituals, as well as the skills of planting and picking directly from him. In so doing, he becomes aware of his grandfather's commitment to early morning observances and to the systematic running of the farm, becoming

6. Where known, dates when the poems were written are given following date of their publication.

7.In theory, Yiddish has no capital letters. However, for reasons of clarity, persona names have been capitalised throughout this article.

8.Phylacteries. 
cognizant of how the other man contains his temper and keeps his own counsel; even when he is annoyed he continues working:

Un beyz iz gevezn der zeyde un tomid fun shvaygn gehaltn, Gebrodzshet tsevishn di yodles in mokh dem tseshoybertn, kaltn, Biz zun flegt oyf shpitsn fun beymer a royte zikh zetsn farleshn.

[And when he became angry, my grandfather diligently kept silent,

Plodded between the firs through the dishevelled, cold moss Until the red sun disappeared behind the peaks of the trees.] (11. 23-27 [author's own translation])

However, there were times when his patience wore thin and he reprimanded the children:

Nor plutsim a brum tut der zeyde: 'vos shteytstu di hent in di bokes? S'i shpetike nakht dokh gevorn, shoyn tsayt dokh dos ferdl tsu shpanen'. [But suddenly grandfather growls: 'Why are you standing with your hands on your belly?

It's already late at night, it's time to harness the horse'.] (1l. 80-81 [author's own translation])

This vignette displays what may be described as a 'sensitivity and openness to responses' (LaCapra 2001:105), as the poet recognises that his grandfather is not always a paragon and is only human. The old man thus also takes time to relax and view the outcome of his labours:

Lozt langzam, pamelekh baym zayt funm vogn zikh sprayzn,

Un s'knoylt zikh gedikht fun zayn pipke a roykh a farnepelter, groyer, In shtilen baginen farflokhn in zilberne krayzn.

Tsufridn fartsiter dem roykh in di lungn mit etlekhe tsien.

[Very slowly he would stride beside the wagon,

And a grey foggy smoke would thread thickly from his pipe,

In silver circles in the quiet dawn.

The smoke thrills in his lungs with each satisfied draw.] (11. 42-45 [author's own translation])

As his zeyde makes his weary way home, the smoke from his pipe mingles with the dawn light, his 'hent hobn zayne geshvartst zikh'/'his hands blackened' (1. 20) after the work is done; only then 'hot zikh geaylet shoyn der zeyde in khate di vetshere esen' / did 'my zeyde [hurry] to his home to eat dinner' (1. 28). Thus, the poet conjures up a picture of an individual who is comfortable within himself, settled in his environment and dedicated to his work, even though his labour is hard. At the end of the day a warm hearth awaits him; there his neighbours gather to chat and celebrate together:

Un do, in dem kleynem, faroykhertn shtibl mit blotike, erdike diln,

Do flegn shadkhonim fun gegent farforn, di mumes shidukhim do reydn.

Do kumn klezmorim oyf mazel tovs, simkhes, oyf khasenes freylikhe shpiln.

Un ale - me shpirt zikh gemitlekh un heymish baym altn yishuonik, dem zeydn.

[And here, in the small, smoky room with muddy, earthen walls, The matchmakers journeyed from afar, spoke about the engagements.

They offered their good wishes and played musical instruments at celebrations and weddings.
And all - felt cozy and happy at the old village Jew, my grandfather.] (1l. 182-185 [author's own translation])

This hardworking farmer, in tune with the land and his surroundings, became Fram's poetic prototype. In so doing, his empathic response 'limits objectification' (LaCapra 2001:102), as can be observed in the character Reb Itshe in Fram's poem 'In a zunikn tog', who is similar to the poet's zeyde in both stature and in his connection to nature:

Un ot, in aza min baginen gezesn aleyn iz reb Itshe

In hoyf oyf a kupe mit kletser, gevaremt zikh unter di shtraln.

[And here in the faint dawn reb Itshe sits alone

In the yard on a heap of wood, warming himself in the sun's rays.] (11. 45-46 [author's own translation])

As Reb Itshe sits contemplating the dawn, warmed by the rising sun, he savours the smell of the 'frishe' /'fresh' (1. 47) dawn, as 's'blien dos frukhtbeymer' / 'blooming of the fruit trees' (1. 51) and the 'bletelekh roze'/the 'rose petals' that sway in the breeze. Similarly, the central character in the poem 'Reb Yoshe un zayn gortn' ${ }^{\prime}$ is a forest Jew who knew every berry and mushroom by name. This poem emphasises the synergistic relationship between the man and the land, alternating the descriptions between them:

Si Yoshe alts a hant, fun altsding vil er visn:

A burikl, a mer, an ugerke mit pupn.

[So Yoshe wants to know it all, as if filling his hand:

A little beetroot, a carrot, a cucumber with pips.] (11. 13-14 [author's own translation])

Season by season, Reb Yoshe was committed to planting and tending his radishes, cucumbers, beetroots, and 'aportn' (a Lithuanian apple), until the time comes for the harvest, to pluck the cucumbers and crush juice from his berries:

Dan yedn shtiln herbst klaybt Yoshe zikh tsuzamen

Di yagdes in a flash un tsukert ayn mit bronfn.

A zeltener getrank, vos shmekt in toyzent tamen.

[Every quiet autumn Yoshe gathers

The berries in a bottle with sugar and liquor

A special drink that tastes of a thousand flavours.] (11. 41-43 [author's own translation])

And having picked his crops and savoured the fruits of his labour, he, like Fram's grandfather, is filled with contentment:

Dan kvelt er on fun freyd, vos shpart fun ale zaytn

Fun hartsn un fun dr'erd, fun kelmishn un tsvaygn.

Un s'trogt zikh aza glik arum in tife vaytn;

Un altsding horkht zikh tsu tsum shabesdike shoaygn.

[Then he beams with happiness, which flows from every side

From heart and from earth, from tree stumps and branches.

And such joy fills the entire expanse;

And everything takes heed of the Sabbath-like quiet.] (11. 125-128

[author's own translation])

This stanza again highlights the close relationship between the man and his natural environment. Feelings of joy course 9.The publication of this poem in the New York journal Oyfkum (1927) brought Fram into the international arena of Yiddish poetry' (Sherman 2006:7). 
through both 'hartsn' /'heart' (1. 126), the man's core, and 'erd' /'earth' (1. 126), the source of nature's growth, and the sap flows upward into the trees. All this is seen in conjunction with the aura of observance, the 'shabesdike shvaygn'/'the Sabbath-like quiet' (1. 128). Thus, the poem again focuses attention on one who is at peace with his environment that he knows so well, where he has grown up and where he enjoys restoration and spiritualisation on the designated day of rest.

The lifestyle of Fram's grandfather and Reb Itshe is alien to the poet, as the older men perform duties with which the poet is unfamiliar. However, the men are nevertheless his familiars, being members of his closely knit community; hence, they conform with Hite's suggestion that 'empathy is more readily induced from "those who seem like us"' (Hite 2015:42), and this is indicated in the poet's respect and love for his grandfather, and his understanding of the characters of Reb Itshe and Reb Yoshe.

Similarly, empathy is the essence of Fram's poem 'I $k h$ benk' ['I long'], as the poet remembers a lifestyle that was lost, and a community that laboured to eke out a living in 'dorfishn umet' /'village sadness' (1. 4). He continues to retain an 'association with ... people, families, communities and the intangible values they share' (Cesarani, Kushner \& Shain 2009:40; Frankel 2013a:28; Frankel 2013b:28). Recognising the arduous life, the 'poyerisher pratse' / 'peasant toil' (1. 4), and the suffering of the animals, 'mide, tseveykte, farshpetikte, elnte ferd'/'tired, swaying, late and forlorn horses trudge along' (1. 3), engulfed by the 'shvere farmatete vokh'/'exhausting weekday gloom' (1. 8) in the 'groyer, farshvigener velt' / 'grey silent world' (1. 16), and worn down by fatigue after the weekday toil, they would 'drag themselves home for shabes'/'vos shlepn aheym zikh oyf shabes' (1. 7), the poet empathises with the struggles of the 'Yidn fun velder, vi kuperne yodles farpekht/Vos shmekn in friyike reykhus fun shvomen un varemen mokh'/"Jews of the forests, solid with firs,/reeking of warm moss and mushrooms' (Fram 1931:5-6).

Thereafter, once the poet had left his family and friends, he embraced the stranger, as exemplified in the poems 'Fun shop tsu shop' ['From shop to shop'] (Dorem Afrike July-September 1984) and 'Matumba' (Fram 1983b:85-88); therefore, the memories of the men he admired and his own experiences of hardship may have influenced his attitudes going forward. My interpretation focuses on the poems' subjective and 'affective' response (LaCapra 2001:38), where the poems encompass 'desirable interactions between self and other' (LaCapra 2001:39), as opposed to 'a strategy of objectification and sustained ironic distance' (LaCapra 2001:39).

\section{Fram's South African portraits}

Fram, like many other immigrant writers to South Africa, continued to use Yiddish as a living and vibrant language and also continued to refer to Eastern Europe as home, di heym. Amalgamating their experiences of past and present despite the pressures of acculturation, their Eastern European Jewish culture became part of the literary culture in the far-flung diaspora of Africa. In this way, they transposed their history and background onto new soil, thus making their mark on their re-constituted communities. Viewed from a distance, home often became idealised through memories of 'activities, or a satisfaction in simple living, or an absence of negative emotions, or the joy of being in or cultivating a garden, of children growing up, of particular trees and shrubs, [and] associations with particular people or special sites' (Cesarani, Kushner \& Shain 2009:30). In his article, 'Yiddish literature in South Africa' (Dorem Afrike 1956:21), Wolpe noted that the revolutionary ideas that were very much part of Eastern European Yiddish poetry were superseded in South Africa by descriptions of personal experiences.

However, although Lithuania strongly 'shaped his literary identity’ (Frankel 2013a:28; Frankel 2013b:28), Fram’s Yiddish poetry also registered profound geographical, social and cultural changes, breaking new ground in a new locale, exploring and expanding its possibilities. As he began to 'notice Africa, Africa began to dominate his poems ... [and] he was inspired and determined to go along that path' (Ravitch 1931:403). Consequently, his poems became filled 'like an African pineapple with juicy Lithuanian Yiddish speech; his Yiddish language as rich as a pomegranate' (Ravitch 1931:403). In the lyrical verse of 'In an afrikaner baginen' ['In an African dawn'] and 'Oyf transvaler erd' ['On Transvaal earth'], he celebrates nature's bounty; these poems evoke Africa's 'pulsating vibrancy' (Sherman 2004:41) and its 'stony soil and scorching skies' (Sherman 2004:7). In addition, poems such as 'Fun shop tsu shop' ['From shop to shop'] and 'Matumba' ['Matumba'] describe the predicament of the black man, while 'Burn' ['Farmers'] focuses on the experiences of local farmers, people who are affected by their physical landscape.

Set in the Transvaal, ${ }^{10}$ the poem 'Fun shop tsu shop' describes the predicament of the black African protagonist who comes from a rural area to seek employment in the city, and LaCapra's suggestion that 'emotional response comes with respect for the other' (LaCapra 2001:40) offers a useful tool when analysing the poem.

The first stanza provides the urban setting as the black outsider searches for a way to earn a living:

Azoy a gantsn tog - fun shop tsu shop-

Iz er arumgegangen betlendik a dzhob ${ }^{11}-$

A shtikl arbet zol men im vu gebn.

[A whole day like this, from shop to shop

He went round begging for a job -

Hoping someone would give him a bit of work somewhere.] (1l. 1-3 [author's own translation])

10.This was a separate province in South Africa, part of which is now known as Gauteng.

11.English names have been transliterated in Yiddish. This is in line with the poet's usage in the poems. 
The struggles of the other man to earn a living mirror Fram's own, working in a concession store on the mines when he first arrived in South Africa, as indicated in his poem 'Ikh Benk'. His own victimisation may be inferred from the poet's personal and communal history, vis-a-vis the widespread oppression of the Jewish community in Eastern Europe under the czars, and its forced relocation in 1915, circumstances that may have enabled him to 'identify with ... other oppressed people' (Davis 1988:46). This may also relate to LaCapra's suggestion that 'empathy is an affective component of understanding' (LaCapra 2001:102), so that rather than objectifying the other person, one, in this case the poet, is affected by his situation. As this affect becomes transferred, the poems suggest an empathetic response to the experiences of others who have been uprooted. Though unable to speak the other's language, the poet recognises that they are nevertheless alike.

The poem goes on to describe the protagonist's physical strength and his purposeful attempt to make a life for himself against the odds:

Er iz geven yung un kreftik vi an ayzn

Un dafke hot zikh im gevolt nokh lebn.

[He was young and strong as iron

And yes, he still wanted to live.] (1l. 4-5 [author's own translation])

As the labourer trudges on, his difficulties weigh him down, and when no one takes pity on him, he pleads with the shop owners. However, in spite of his arduous efforts, his search for work proves fruitless in the face of indifference and he feels hopeless:

'Vork, ay vont tu vork... may bas, ay vont a dzhob'...

Nor keyner ruft zikh oyf zayn betenish nit op -

['Work, I want to work, my boss, I want a job'...

But no one responds to his begging -] (11. 15-16 [author's own translation])

Here, the poet's empathic response evokes the plight of the other. However, according to LaCapra, empathy also 'resists full identification with, and the appropriation of, the experience of the other ... and the recognition that another's loss is not identical to one's own loss' (2001:79). LaCapra terms this differentiation and separation from the other's situation 'empathetic unsettlement' (LaCapra 2001:103). Hite refers to it as a 'reaching for, yet not being able to grasp, someone both familiar and unfamiliar' (LaCapra 2001:43). Thus, the poet is affected by the other man's difficulties, putting himself in the other's place. However, 'the experience of the other is not [his] own' (LaCapra 2001:40); it is not his struggle:

Derlangt men mer nit shtil a shokl mitn kop:

Neyn, nito keyn arbet do, farshteyst? - Neyn!...

Un vider veys er vayter shoyn nit vu tsu geyn.

[They give him nothing more than a shake of the head:

'no there is no work here, understand? - No!...

And once again he does not know where to turn.] (11. 17-19

[author's own translation])
Clearly, unlike the poet, the shop owners from whom the other man seeks employment have no compassion for his situation:

Er hot azoy fil gute, vayse mentshn shoyn gezen Un keyner hot zikh iber im a hungerikn nit derbarmt Mashmoes, keyner darf nit hobn do zayn pratse un zayn shveys.

[He has already seen many good, white people And no one yet has taken pity on him in his hunger,

Presumably, no one here needs his labour and his sweat.] (11. 21-23 [author's own translation])

As the memory of his last meal plagues the labourer, he is overcome with longing for the taste and heat of food; this overtakes every other need: 's'triknt im di shpayekhts azh fun hunger in zayn moyl' / 'when hunger still dries the saliva in his mouth' (1. 30), his hopelessness embedded in the trudging rhythm of the lines:

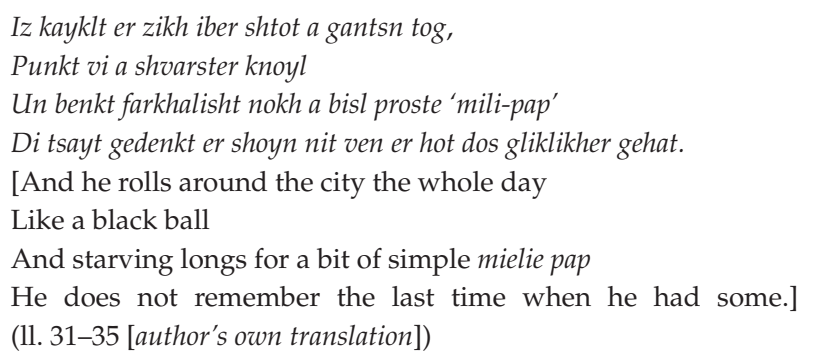

While Fram would have hankered after the traditional staples grown by his grandfather, 'burekes' [beetroot] (1. 22), and 'bulbes' [potatoes] (1. 20), the black man craves his pap, his porridge. His mouth waters as he imagines how he would:

\section{Shepn shporevdik mit alemen fun heysn blekh}

Dos aynkaykln in zayne shvartse hent s'zol vern shvarts vi pekh

Un nokhdem leygn dos mit groys hanoe in zayn moyl.

[Scoop up carefully from a hot tin with everyone

Rolling it in his black hands so it becomes as black as pitch

And then putting it in his mouth with great pleasure.] (11. 37-39 [author's own translation])

Eating straight from the container, the starving man helps himself to the porridge, rolling it from one hand to the other to cool it, his hands becoming black with charcoal and ash. The use of the vernacular 'mili-pap' for porridge indicates the poet's awareness of the difference in his new environment. As Fram observes the other man as though he were experiencing his hunger himself, the poet feels close to him, yet maintains his separateness. However, in spite of obvious differences, the poet relates in unexpected ways to the other man, empathising through perceived or implied similarities. McEwan comments 'It is hard to be cruel once you permit yourself to enter into the mind of the victim. Imagining what it is like to be someone other than yourself is the core of our humanity. It is the essence of compassion, and it is the beginning of morality' (McEwan 2001). Written by a Yiddishspeaking white immigrant and steeped in the language and customs of the local inhabitants, 'Fun shop tsu shop' is unique for its time. 
Similar to the lyric 'Baym zeydn', the long poem 'Matumba' (Fram 1983b) idealises the peace of country life, highlighting the protagonist's bond with the land in a mutually beneficial relationship. Again, the poem indicates Fram's empathy towards country people, who are similar to his grandfather and Reb Yoshe in the Lithuanian poems. Elevating the protagonist to heroic status, the narrative illustrates how the urban environment can destroy the outsider. LaCapra describes the nature of this response as 'a kind of virtual experience through which one puts oneself in the other's position' (LaCapra 2001:78) in order to limit the 'objectification' (LaCapra 2001:102) of that other. While his statement makes particular reference to Holocaust victims, this may also be applied to the predicament of the other in more general terms

Hence, the poet's reaction to Matumba's circumstances may again be read as one of empathy, as Matumba leaves the familiarity of his kraal in search of work with white employers in the city. Having lost his home, his family and his traditional way of life lived close to the soil, he falls victim to the white man's pass laws. ${ }^{12}$ Alienated and naïve in the cultural clash between the traditional customs of lobola ${ }^{13}$ and polygamy as opposed to monogamy, these tensions ultimately contribute to misunderstanding and personal calamity for him.

The first stanza sets the scene in the bushveld where Matumba lives peacefully with his wives and livestock, 'Matumba iz gekumen fun vaytn kral, ${ }^{14} / . . . /$ Ergets-vu in a vinkl fun Transvaal,/Iz gebliben zayn royte, erdishe khate'/'Matumba came from a distant $\mathrm{kraal} / . . . /$ Somewhere in a corner of the Transvaal,/His red, simple home remained' (11. 1; 2-4). Matumba had 'dray vayber/Tsu pashn in kral zayne ki/'three wives/To look after his cattle in their kraal' (1l. 5-6). These descriptions highlight aspects of kraal life, the customs and sense of community through shared rituals that were left behind when they left. While these imply the differences between the lifestyle of Fram's community and that of the indigenous black people of South Africa, they also suggest how in both cases their uprootment lead to their sense of alienation.

The description also embodies the poet's 'affective response' (LaCapra 2001:105); rather than objectifying the other person, the poet's earlier empathy and admiration for his grandfather, stemming from familiarity and similarity, carries over to the stranger's circumstances. A congenial link is created through the use of the term 'khate' /'home' in both 'Matumba' (1. 1) referring to Matumba's mud hut, and in 'Baym zeydn' (1. 28), referring to the old man's wooden farmhouse.

Similarly, both the poet's zeyde and the tribal chief Matumba were short of nothing and were content with their idyllic way of life:

12.'Pass' (dompas). The identity document that every black person was required by law to carry at all times.

13.Amongst Zulu, Xhosa and Ndebele tribes, it is customary for the bridegroom to pay the bride's family before the marriage can take place.

14.Words such as kraal and assegaai have been spelt according to Yiddish rules when transliterated, but in their vernacular spelling using italics in the English translations.
Er iz geven tsufridn mit dem vos er hot shoyn gehat,

Er hot gevust, az er hot zayne vayber shtark holt

Un shlofn hot er gekont mit zey tsu zat.

[He was happy with what he already had,

He knew that he loved his wives greatly

And he could sleep with them to his fill.] (11. 22-24 [author's own translation])

Matumba's peace is 'tseraysn'/'torn' (1. 36) apart when he is obliged to go into the city to earn enough to pay his taxes, which 'ober dray yor gehat nisht batsolt'/'he had not paid for three years' (1. 39). He leaves the security of his enclave:

Ale dray vayber ... bay zikh aheym.

Oy, hot er zikh biter zey dan gezegnt.

[All three wives ... behind at his home

Oy, how bitterly he bade them farewell.] (11. 45-46 [author's own translation])

This situation is in direct contrast to what Matumba experiences in the city:

Ekh, flegt im reytstn ir nakete, shvartse brust,

Ir boykh azoy rund, azoy shteyf - nokh gor vi a besule.

[And, he would tease her naked, black breasts,

Her round belly, still firm as a maiden's.] (11. 31-32 [author's own translation])

This description also provides an insight into local customs and obligations to which Matumba is committed. Hence, he pays lobola of twelve oxen for his favourite wife Sesula who is 'Vi a zeltener ferd in stadole' / Like a rare horse in the herd' (1. 32). Fram perceives Matumba's as a blissful existence, in line with his romantic perception of peasant life as similar to that of his grandfather, and also a projection of his own fantasies.

Like Matumba, Fram was used to the quiet life on the land of 'Baym zeydn' and 'Reb Yoshe in zayn gortn' and the contrast in circumstances as he moved to the city came as a shock to him; although the poet does not employ the poem as a didactic platform for his political opinions, or specifically as a contrasting reference point to the Jews of Lithuania, whose lives were also disrupted, his empathy for the other man emerges as Matumba's life unravels.

Matumba's conditions of work are arduous, a complete contrast to his status as leader of his tribe. Weakened by this lifestyle:

\section{Itst ligt er azoy vi a kretsiker hunt}

Un klaybt brekelekh fun tish bay dem vaysen.

[Now he lies like a scratching dog

And collects scraps from the table of the whites.] (11. 67-68 [author's own translation])

As he is sapped of his physical strength, 'Iz Matumba gevorn farshrumpn fun tsar,/Er hot zikh ingantsn gebitn' /'Matumba shrank with grief,/He became completely changed' (1l. 81-82). He longs for 'zayn khate'/'his home' (1. 52), a yearning with which Fram would have identified, as discussed with reference to the poem 'Ikh Benk'. 
Matumba also wants 'Zayn "asegay"15 hot er sheyn lang nit gesharft' / 'He hadn't sharpened his assegaai in so long' (1.55), identifying him as a warrior amongst his own people. As protector of his clan, 'in hartsn gebrent hot a fayer'/'in [Matumba's] heart there burned a fire' (1. 56), when he becomes anxious that some ill may befall Sesula because he is not there to protect her. Fram relates to Matumba's difficulties, having been similarly dislocated, obliged to spend endless days in the city in response to economic pressures.

While Matumba does the chores, dusting his employer's house, polishing the floors on his hands and knees, he watches her performing her intimate ablutions:

Zi-ire hor flegt zi kemen,

Halb-naket un rayznt azoy vi a leyb-

Zi flegt zikh far im gornisht shemen.

[She would comb her hair,

Half-naked and alluring like a lion,

She was not embarrassed in front of him.] (11. 90-92 [author's own translation])

Straightening her still-warm bed, Matumba sees her putting on her clothes, one item at a time:

\author{
Un tsaytvays flegt zi in shtayfn korset \\ Farshnureon hart ire brustn, \\ Dan flegt er arayngeyn farbetn dos bet, \\ Nokh varm fun tayve un glustn. \\ [And sometimes she would lace her breasts tightly \\ in a stiff corset, \\ Then he would go in and straighten the bed \\ Still warm with lust and glowing.] (1l. 93-96 [author's own \\ translation])
}

This vignette highlights the seductive behaviour of his employer as he worked in her close proximity and its impact on him. The scene also offers a foil to the earlier one in which Matumba as chieftain danced freely with his halfunclothed wives, Fram perhaps identifying with Matumba's predicament.

In a state of confusion at the sight of his mistress's state of undress, Matumba is filled with longing for Sesula, his true love, so that:
... eynmol in friling hot er bay ir tir
Gevart vi a khaye farborgn
Er hot zikh meshuge gevorfn oyf ir
Un hot zi shir-shir nisht dervorgn.
[... once, in spring by her door
He waits like a concealed animal
As a mad thing he threw himself at her
And he choked her.] (11. 101-104 [author's own translation])

Unable to control himself, overcome with longing for his wife, Matumba forces himself on his mistress, until they become nothing but 'Tsvey kerpers tsemisht'/'Two bodies intertwined' (1. 109), one black and one white. Found guilty of murder, Matumba goes to the gallows alone, far from his beloved:

15.Traditional Zulu hunting weapon.
Fartsitert, gefaln, Matumba iz toyt,

Oh, Sesula, Sesula.

[Struck with fear, fallen, Matumba is dead,

Oh Sesula, Sesula.] (11. 119-120 [author's own translation])

Away from his familiar territory and in the midst of an alien culture, the warrior and patriarch of his own people, who is nothing more than a servant to his employer, loses his sense of worth and dignity - and ultimately his life. The poet's view of his grandfather may have influenced how he saw Matumba whose difficulties may then have been related to how he experienced the loss of his own idyllic past and his own move to the city where he was a foreigner and outsider. The poet's understanding of the dislocated man's circumstances may be related to his own experiences; being able to imagine himself in the other man's place, Fram's empathy remains intact.

In the poem, 'Burn'16 the lifestyle of white Afrikaner farmers in their smoke-filled parlours in the platteland ${ }^{17}$ may again be related to that of the poet's grandfather in 'Baym zeydn':

Mit halbn tog-gekumen iz a fule shtub mit gest;

Di burn in garniters oysgeputst

Mit breyte hit un hengendike grobe hent.

[At midday there was a full room of guests

Farmers dressed up in their best outfits,

With broad hats and huge hands.] (11. 1-3 [author's own translation])

In this manner, the farmers enjoy a day of leisure, listening to music, talking and relaxing as they:

Gezupt di kave fun der flakher shal,

Zikh tsugehert geshmak tsum gramafon

Un emese hanoe do gehat.

[Sipped coffee from the saucer

Listened with pleasure to the gramophone

And had true enjoyment.] (11. 46-48 [author's own translation])

Like Reb Yoshe and Reb Itshe, this farmer is also satisfied after a day in the field, surveying and harvesting his crops, and he 'Derlangt a lek dem shpits mit naser tsung/Un take zikh bagavert bay derbay'/'Licked the tip (of the cigar) with a wet tongue/And really enjoyed it' (11. 56-57), Later, with his neighbours keeping him company in a smoke-filled room, 'Di paypn hot men oysgebitn'/'The pipes were exchanged' (1. 62). The leisure time that the farmer spends smoking cigars is again reminiscent of the vignette in 'Baym zeydn' when the grandfather takes time out to smoke, his 'piepke'/'pipe' (1. 43), indicating the affinity between people who work the land, the 'burn'/'farmers', in South Africa, and relating this to his grandfather at home.

The farmers' bodies reflect their satisfaction during their neighbourly get-togethers, sitting separately from their wives, lethargic in their Sunday best:

16.The poem was published in full in Lider un poemes (210-249). The title refers both to the fact that they are farmers and also that they are Boere, that is, Afrikaners.

17.This refers to the outlying countryside. 


\section{Di vayber zaynen do gezesn mat}

Mit kerpers ongegosene mit schmaltz,

Mit fete geyders un mit fule brist,

Azoy, az shver gevezn iz tsu geben zikh a rir.

[The wives sat there listlessly

Bodies covered in fat

With fat arms and full breasts

And it was difficult to move themselves.] (1l. 4-7 [author's own translation])

The enjoyment they experience when they are together is further emphasised in lines such as 'Azoy hot men in eynem zikh farbrakht/Gemitlekh in der yomtovdike ru'/ That is how they all passed the time/Companionably in celebratory rest' (1. 66-67), evoking the gathering that took place at Fram's grandfather's farmhouse in 'Baym zeydn' and the abiding contentment that comes after a long working day they share.

\section{The Holocaust}

The Second World War (1939-1945) brought with it the decimation of the Jewish population of Eastern Europe, but Fram escaped, having left his home there before the genocide, in which his parents and community perished. While his poems make no claim to be historically factual, 'literary texts are essential, if not to restore the record through speculation, then to mark the spaces, gaps and aporias that cannot be filled' (Frankel 2013a:57; Frankel 2013b:57; Peterson 2001:9). Hence, although they are accepted modes of recording history, documents and archives may 'prove inadequate in the face of trauma, as straightforward facts alone may be unable to access real history, nor fully acknowledge its physical and emotional horror' (Frankel 2013:57). They may also be both 'inaccurate and unreliable in accessing personal responses or feelings or reactions' (Frankel 2013a:57; Frankel 2013b:57).

Instead, as Peterson suggests, the experience of victims calls for 'alternative language forms to witness ... the crisis within history which precisely cannot be articulated' (Peterson 2001:7). Rather than deploying the factual depositions of historical documents, poetry's multi-levels, metaphor and multi-layering may more deeply reflect the impact of personal experience, where 'imaginative speculation' (Frankel 2013a:57; Peterson 2001:9) offers an avenue to evoke compassion and empathy. Hence, poetry draws the reader close to the subject and the experience, as may be intuited through Fram's poems, but in a manner that history cannot and does not.

Thus, where LaCapra indicates that '[e]mpathy is important in attempting to understand traumatic events and victims' (LaCapra 2001:78), Fram's poem 'An entfer der velt' ('An Answer to the World') (Fram 1971a:50; Frankel 2013a:39; Frankel 2013b:39) offers his personal response to historical events, deepening the reader's insights and understanding, for example:

Ikh fil, ikh trog oyf zikh tsurik di gele late.

Fun vaytn knoylt zikh nokh fun kalkh-oyon der roykh.

[I feel I wear the yellow star once again.

In the distance, there still billows the smoke from the lime-kiln.]

(11. 1-2 [author's own translation])
As the poet imagines himself pinning the fateful badge to his own breast, he aligns himself with the victims as though he himself were trudging to his death. Rather than distancing himself from the carnage, through this testimony, the poet sets up an intimacy with the victims, and locates himself within the scene.

In the poem's next image, attention turns to the poet's father as he breathes his last, his prayer merging with the smoke from the chimney above the ovens:
Vu s'hot zayn letstn Shma Yisroel ${ }^{18}$ oysgelebt mayn tate,
$V u$ s'hot mayn mame oysgehoykht ir letstn hoykh.
'An entfer der velt'
[Where my father lived out his last Shma Yisroel,
Where my mother breathed her last breath of air.] (1l. 3-4 [author's own translation])

In these lines, the poet's compassion and empathy seem to be carried with the wisp of smoke; these are not anonymous victims but his parents and his community:
Vu brider zaynen tsu dem toyt farlitene gegangen,
$V u$ oyfhelekh geshtelt hobn in vakl zeyer shtiln trot.
'An entfer der velt'
[Where brothers went to their deaths with resignation,
Where infants trod their quiet shaky steps.] (11. 5-6 [author's own translation])

So closely bonded is he with his community that the poem becomes a testimony as he describes how he accompanies them on their way to 'the pyre'/'dem shayter' (1. 17) and 'eshafot'/'execution scaffolds' (1. 20). As the perpetrators show no mercy for their victims: 'Hot men keseyder unz geharget un gevorgn' / They constantly killed and choked us' (1. 13), the poet is deeply affected and filled with compassion for them; imagining himself in their position, with the recognition of their suffering, arousing his, and our, empathy for their plight (Stonebridge 2015).

However, in order to avoid over identification or the 'total fusion of self and other' (LaCapra 2001:38), LaCapra points out the 'dubious usefulness of identifying with the victim to the point of making oneself a surrogate victim who has a right to the victim's voice or subject position' (LaCapra 2001:78). He emphasises the need to avoid 'confus[ing] one's own voice or position with the victim's' (LaCapra 2001:78), and warns of the dangers of implicating the observer in the observed, with its 'possibility of transference' (LaCapra 2001:36). Thus, the better empathic response would be a qualified one, so that 'being responsive to the (traumatic) experience of others, notably of victims, implies not the appropriation of their experience but empathic unsettlement' (LaCapra 2001:41). This would involve 'recognizing the difference of that position and ... not taking the other's place' (LaCapra 2001:78).

Fram remains strongly connected to the country of his birth; as he witnesses what has happened there, he aligns himself with his fellow countrymen. His heartbroken cry

18.'Hear Oh Israel ...', the first words of the prayer recited morning and evening, and at the time of death (Deut 6:4-9). 
in 'Dos letste kaptil' is indicative of this ongoing connection to his birthplace and how his own loss is encompassed in the deaths of those he holds dear, an expression of empathic connection that serves as a memorial to what was destroyed.

Viewing the ruler-murderers from the standpoint of the oppressed, he expresses emotions that can have no place in official histories:

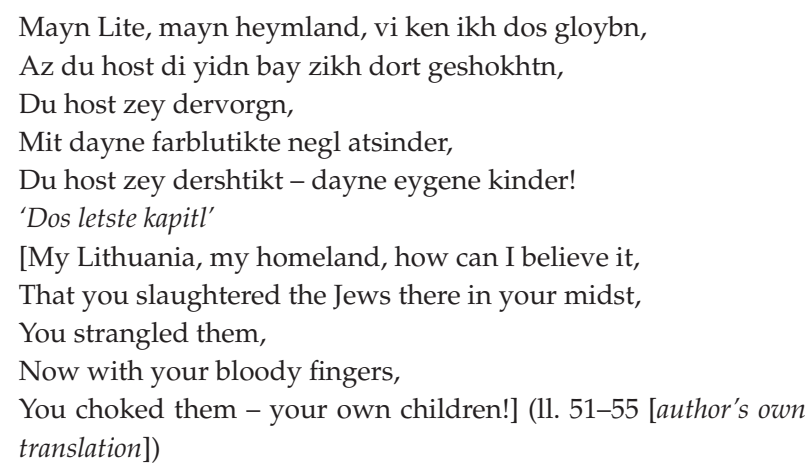

By addressing Lithuania as 'Mayn Lite, mayn heymland' (1. 51), he indicates both a possessive affection for it and accuses his own neighbours and countrymen, the Lithuanians, of perpetrating the crime. Whereas once the country embraced her Jewish children, 'Azoy vi a mame'/'like a mother' (1. 7), afterwards, all that was left was the 'meysim, harugim un kupes mit beyner'/'murdered, the dead and piles of bones' (1. 49), which was overrun by 'A yomer fun kreyen vos pikn di beyner' /'A lamentation of crows that pick the bones' (1. 47).

As the poet identifies with the victims, he vows to take up arms against the perpetrators, to take: 'nekome far alte farpaynikte zeydes,/Far gantse fartilikte yidishe eydes' / Revenge for old tortured grandfathers, / For entire annihilated Jewish communities' (11. 85-86).

Nor ven kh'volt itst kenen a meser a sharf ton,
A sharf ton a meser azoy vi a britve,
Volt ikh dayne merder, mayn yidishe Litve,
Di gorgls tseshnitn mit heyser nekome.
[But if I could now sharpen a knife,
Sharpen a knife like a razor,
I would cut the throats of your murderers,
My Jewish Lithuania, in burning revenge.] (11. 78-81 [author's
own translation])

These poems evoke Fram's personal responses to the fate of a silenced people and his anger on their behalf, lines that also serve as testimony. As much as he feels compassion for them, so does he wish to avenge their murder.

In Lost in translation (1998), Eva Hoffman describes her parents' experiences and escape from the Nazis in occupied Poland; because she herself did not suffer, she can make no sense of it. She wants to feel their pain but cannot. Instead she is overcome with guilt (Hoffman 1998:24). Fram, having left Lithuania when he did, also escaped, and this poem reflects his feelings of compassion for those who perished, as well as his anger on their behalf.

\section{Conclusion}

Fram never returned to the country of his birth but his early experiences there continued to influence him throughout his life. Embedded in his poetry of Lithuania and South Africa are narratives referencing the people living there and the circumstances that confronted them. This article argues that the poems that refer to those whom he knew well, his grandfather and men of the soil, the strangers whom he observed who were out of their own milieu as he was, as well as the victims who perished in the Holocaust, demonstrate empathy as a driving force. As a carrier of memory and history, the Yiddish language continues to enrich our understanding of a specific time and place; it also reminds us of the persistence of the conflicts caused by intolerance. Thus, Fram's poems remain valuable today, for both their literary value and their content.

\section{Acknowledgements}

I would like to thank Shifrah M. Fram, David Fram's daughter, for permission to translate and use the poems in my research; Mr Cedric Ginsberg and Dr Khayke Beruriah Wiegand for their assistance with the translations and transliterations; Professor Merle Williams for her enriching insights, and the National Research Foundation for its generous support. I also wish to acknowledge the advice and suggestions made by the anonymous reviewers, but I take full responsibility for the views expressed in this article.

\section{Competing interests}

The author declares that she has no financial or personal relationships, which may have inappropriately influenced her in writing this article.

\section{References}

Cesarani, D., Kushner T. \& Shain, M. (eds.), 2009, Place and displacement in Jewish history and memory. Zakor v'makor. Vallentine Mitchell, London.

Cohen, N., 2010, The Yivo encyclopedia of Jews in Eastern Europe, transl. R. Hann, viewed 4 April 2011, from http://yivoencyclopedia.org/Literarishebleter

Davis, B., 1988, 'David Fram, Yiddish poet', The Jewish Quarterly, Winter, 45-49.

Fram, D., 1931a, 'Baym zeydn' ['At grandfather's'], in Lider un poemes [Songs and poems], pp. 147-209, D. Krejnes, Vilna, Poland.

Fram, D., 1931b, 'In a zunikn tog' ['On a sunny day'], in Lider un poemes [Songs and poems], pp. 123-132, D. Krejnes, Vilna, Poland.

Fram, D., 1931c, Lider un poemes [Songs and poems], D. Krejnes, Vilna, Poland.

Fram, D., 1931d, 'Reb Yoshe un zayn gortn' ['Reb Yoshe and his garden'], in Lider un poemes [Songs and poems], pp. 91-99, D. Krejnes, Vilna, Poland.

Fram, D., 1971a, 'An entfer der velt' ['An answer to the world'], Dorem Afrike, July-August, p. 50.

Fram, D., 1971b, 'Burn' ['Farmers'], Dorem Afrike, May-June, p. 13.

Fram, D., 1983a, A shvalb oyfn dakh [A swallow on the roof], Kayor, Johannesburg.

Fram, D., 1983b, 'Matumba' ['Matumba'], in A shvalb oyfn dakh [A swallow on the roof], pp. 85-88, Kayor, Johannesburg.

Fram, D., 1984, 'Fun shop tsu shop' ['From shop to shop'], Dorem Afrike, July-September, p. 29

Frankel, H., 2013a, 'David Fram: Lithuanian Yiddish poet of the South African diaspora, and Illuminating love', PhD thesis, Department of English, Sheffield Hallam University.

Frankel, H., 2013b, 'David Fram: Lithuanian Yiddish Poet of the South African Diaspora and Illuminating Love', viewed n.d., from http://shura.shu.ac.uk/4914/1/Hazel_ Frankel_David_Fram.pdf

Frankel, H., 2015, 'Journey with two maps: Longing and belonging in the Yiddish poetry of David Fram', The English Academy Review 32(2), 22-37. http://dx.doi. org/10.1080/10131752.2015.1086156 
Hite, K., 2015 'Empathic unsettlement and the outsider within Argentine space of memory', Memory Studies 8(1), 38-48. http://dx.doi.org/10.1177/1750698014552407

Hoffman, E., 1998, Lost in translation, Vintage, Great Britain.

Hunt, L., 2008, Inventing human rights: A history, Norton, New York.

LaCapra, D., 2001, Writing history, writing trauma, The Johns Hopkins University Press, Baltimore, MD.

McEwan, I., 2001, 'Only love and then oblivion', viewed 05 July 2016, from www. theguardian.com/world/2001/sept/15/September11.politicsphilosophysociety.2

Peterson, N.J., 2001, Against amnesia. Contemporary women writers and the crises of historical memory, University of Pennsylvania Press, Pennsylvania.

Ravitch M., 1931, 'Dovid Fram un zayne lider' ['David Fram and his Songs'], Literarishe Bleter, 04 November, p. 403.
Sherman, J., 2004, 'David Fram centenary tribute', pp. 1-17, viewed 16 May 2007, from www.eilatgordonlevitan.com/panevezys/pan_stories_fram.html

Sherman, J., 2006, 'What balm for the heart...? The Yiddish poetry of David Fram (1903-1988)', Midstream, July-August, pp. 7-11.

Simon, J. 2009, 'Jewish identity in two remote areas of the Cape Province: A double case study', in D. Cesarini, T. Kushner \& M. Shain (eds.), Place and displacement in Jewish history and memory, pp. 114-128, Vallentine Mitchell, London.

Stonebridge, L. 2015, 'Sands of sorrow: Rights, refugees and the impasse of empathy', in Transnational Holocaust Memory Conference, Leeds, United Kingdom, January 26-27, n.p.

Stonebridge, L. \& Potter, R., 2014, 'Writing and rights', Critical Quarterly 56, 4.

Wolpe, D., 1956, 'Yidishe literatur in Dorem Afrike' ['Yiddish literature in South Africa'], Dorem Afrike, December, pp. 21-23. 